\title{
Perspektif Masyarakat Pengguna Jalan Atas Ojek Online: Sudut Pandang Kemacetan
}

\author{
Ibram Pinondang Dalimunthe ${ }^{1}$ Nofryanti ${ }^{2}$ \\ Akuntansi, Fakultas Ekonomi, Universitas Pamulang, Tangerang ${ }^{1,2}$ \\ ibram@unpam.ac.id ${ }^{1}$,nofryanti@unpam.ac.id ${ }^{2}$
}

\begin{abstract}
Abstrak
Penelitian ini memberi gambaran dan analisa tentang persepsi masyarakat pengguna jalan terhadap perilaku ojek online pada sudut pandang kemacetan. Metode penelitian menggunakan pendekatan kuantitatif deskriptif yang menjelaskan tujuan penelitian. Populasi penelitian ini yakni seluruh masyarakat pengguna jalan yang berada di wilayah Jakarta, Bogor, Depok, Tangerang, dan Bekasi. Sampel yang dijadikan penelitian adalah masyarakat yang pernah memanfaatkan fasilitas layanan ojek online, serta masyarakat umum yang memiliki pandangan terkait transportasi online. Teknik pengumpulan data menggunakan kuesioner dan disebarkan kepada responden. Hasil penelitian menunjukkan bahwa persepsi masyarakat terhadap ojek online mampu membuat keamanan dan kenyamanan bagi pelanggan, dapat mempermudah aktifitas pengiriman barang, mampu berinisiatif mencari jalan alternatif untuk mempersingkat jarak tempuh, dan biaya ojek online yang terjangkau bagi pelanggan. Namun, di sisi lain responden menyebutkan bahwa keberadaan ojek online dapat menyumbang tingkat kemacetan di jalan, responden setuju agar dibuat shelter khusus untuk pelanggan dan pengemudi ojek online saat menunggu order agar tidak mengganggu aktifitas pengguna jalan lainnya yang berdampak kepada kemacetan.
\end{abstract}

Kata Kunci: Persepsi keamanan, persepsi biaya, persepsi waktu, persepsi kemudahan, persepsi kemacetan

\section{The Perspective of Road Users on Ojek Online : The Point of View Congestion}

\begin{abstract}
This study provides an overview and analysis of the perceptions of road users on online motorcycle taxi behavior from the point of view of congestion. The research method uses a descriptive quantitative approach that explains the research objectives. The population of this study is all road users in the Jakarta, Bogor, Depok, Tangerang and Bekasi areas. The samples used for research are people who have used online motorcycle taxi service facilities, as well as the general public who have views regarding online transportation. Data collection techniques using a questionnaire and distributed to respondents. The results showed that people's perceptions of online motorcycle taxis were able to create safety and comfort for customers, facilitate delivery of goods, be able to take the initiative to find alternative ways to shorten mileage, and affordable online ojek costs for customers. However, on the other hand, respondents said that the existence of online motorcycle taxis can contribute to the level of congestion on the road, respondents agreed that a special shelter should be made for customers and online motorcycle taxi drivers while waiting for orders so as not to interfere with the activities of other road users that have an impact on congestion.
\end{abstract}

Keywords: Perception of security, perception of cost, perception of time, perceived convenience, perception of congestion

\section{PENDAHULUAN}

Teknologi Informasi dan Telekomunikasi (TIK) ditemukan hampir pada semua kehidupan manusia sebagai masyarakat informasi. Persoalan ini mendorong pola kehidupan manusia ke arah yang lebih modern dan praktis (Sani, Wiliani, \& Husain, 2019). Perspektif masyarakat tidak terlepas juga dari adanya 
perkembangan teknologi dalam peran strateginya menggunakan saluran atau jaringan intra maupun ekstranet, hal ini dituangkan dalam keunggulan strategi dalam suatu organisasi (Santoso \& Astuti, 2018). Munculnya aplikasi sebagai buah hasil pengembangan TIK kini menjadi alat yang digunakan hampir pada semua aktivitas manusia di dunia, baik individu maupun organisasi. Di Indonesia, transportasi yang baru-baru ini menjadi booming dengan keunggulan fitur-fitur aplikasinya seperti halnya transportasi online (ojek online).

Keberadaan transportasi sebagai pendukung pergerakan masyarakat idealnya akan memberikan implikasi positif terhadap peningkatan pertumbuhan dan perkembangan masyarakat di Jabodetabek. Berbagai sarana dan prasarana transportasi pun disediakan guna menunjang berbagai aktivitas perekonomian masyarakat Jabodetabek seperti kereta api, bus trans, MRT, LRT, serta sarana transportasi penunjang lainnya. Dalam (BPTJ, 2018) tercatat bahwa jumlah kendaraan bermotor pada tahun 2018 mencapai 24.897.391 unit. Kendaraan bermotor tersebut terdiri atas 2\% angkutan umum, 23\% mobil pribadi, dan 75\% sepeda motor. Sementara, total pergerakan masyarakat di Jabodetabek pada tahun 2018 telah mencapai 50 juta orang per hari.

Arus mobilitas orang yang begitu besar dengan tingkat pertumbuhan kendaraan bermotor yang pesat telah menjadikan keberadaan transportasi juga berimplikasi negatif dalam realitas. Penelitian yang dilakukan oleh (Inrix.com, 2017) sepanjang 2017, menempatkan Indonesia yang diwakili oleh DKI Jakarta berada di peringkat 12 dalam daftar kota-kota termacet di dunia. Peringkat ini diketahui naik dibandingkan tahun sebelumnya yaitu 2016 yang menempatkan Jakarta pada posisi 22. Menurut (Inrix.com, 2017), berdasarkan lama waktu kemacetan yang dirasakan pengendara di Jakarta, dalam setahun rata-rata mencapai 63 jam dengan porsi 20\%. Angka ini juga mengalami kenaikan dibandingkan tahun 2016 yang menyatakan bahwa para pengendara harus menghabiskan waktu 55 jam di jalan saat macet (Tamara B. \& Sasana, 2017).

Sarana transportasi yang efektif dan efisien, kini menjadi kebutuhan yang sangat mendesak bagi masyarakat Jabodetabek di tengah problematika kemacetan yang terjadi. Transportasi yang baik bagi pelayanan publik harus memenuhi tiga kriteria dasar, yaitu kenyamanan, keamanan, dan kecepatan. Ketentuan pertama adalah kenyamanan, yaitu aspek kenyamanan harus dapat dirasakan oleh penumpang yang menggunakan jasa transportasi. Penumpang akan merasa nyaman di dalam sarana transportasi bila pada sarana tersebut dilengkapi berbagai fasilitas yang memberikan kenyamanan bagi penumpangnya (Dagun, 2006). Kehadiran jasa transportasi berbasis aplikasi online yang menggunakan internet sangat berpengaruh terhadap masyarakat dalam segala aktivitas secara cepat dan efisien. Angkutan berbasis aplikasi online khususnya di Jabodetabek semakin populer dengan hadirnya ojek online, taksi online, bahkan bajaj online. Pemesanan angkutan ini menggunakan smartphone dengan cara memasang aplikasi yang bisa di download secara gratis. Setiap user dapat memesan layanan ini dari mana saja. Kemudahan mengakses angkutan yang dibutuhkan dan biaya yang murah tentunya menjadi salah satu alternatif pilihan jenis angkutan bagi masyarakat di wilayah Jabodetabek yang dilanda problematika kemacetan (Sakdiyah, 2019).

Pada tahun 2018, Shopback melakukan riset yang menyatakan bahwa 91\% masyarakat pernah menggunakan jasa angkutan online. Tingginya minat masyarakat tersebut menjadikan angkutan online sebagai salah satu profesi yang cukup diminati. Pada tahun 2018, di Jakarta terdapat 1 juta pengemudi ojek online dan tidak sedikit yang menjadikannya sebagai mata pencaharian utama. Hal ini menjadikan permintaan terhadap kendaraan bermotor menjadi cenderung naik yang berdampak pada pertambahan kendaraan bermotor di jalan raya (Aco, 2018).

Ojek online yang merupakan perpaduan antara ojek konvensional dengan kecanggihan teknologi, telah menjadi instrumen bagi pemenuhan kebutuhan masyarakat Jabodetabek akan sarana transportasi yang efektif dan efisien. Jasa ojek online oleh sebagian besar masyarakat dirasakan mampu menembus kemacetan. Namun, seiring dengan perkembangannya yang pesat, kehadiran ojek online kini justru menjadi faktor yang menyebabkan kemacetan. Bukan rahasia umum apabila ojek online sering menggunakan bahu jalan untuk menunggu penumpang, yang lebih parah bahkan jumlah ojek online yang parkir itu bisa berjumlah puluhan. Akibatnya tentu membuat ruas-ruas jalan menjadi tersumbat dan pada akhirnya kemacetan tak terhindarkan (Maharani, 2018). Kondisi ini berkaitan erat dengan penyediaan tempat (shelter) bagi para pengemudi ojek online agar dalam melakukan antar-jemput konsumen dapat dilakukan secara tertib. Peningkatan fasilitas dan kualitas pelayanan melalui penyediaan shelter merupakan upaya solutif agar ojek online tidak berhenti di sembarang tempat, terutama pada titik-titik yang menjadi pusat keramaian dan berhubungan dengan sistem transportasi massal seperti terminal, stasiun kereta, MRT, LRT, pusat perbelanjaan yang berdampak pada kemacetan arus lalu lintas. Penyediaan shelter juga untuk menjaga agar fasilitas umum yang sering digunakan oleh masyarakat pengguna jalan seperti halte, trotoar, dan bahu jalan tidak terganggu. Selain itu, penyediaan shelter juga merupakan upaya dalam meningkatkan fasilitas dan kualitas pelayanan terhadap konsumen karena konsumen yang melakukan pemesanan adalah bagian masyarakat pengguna jalan. Melalui penyediaan shelter, maka berbagai pengembangan produk yang menjadi kebutuhan pengemudi ojek online 
dalam meningkatkan kualitas pelayanan terhadap konsumen menjadi potensi untuk dapat dikembangkan.

\section{TINJAUAN PUSTAKA}

\section{Persepsi Masyarakat Pengguna Jalan}

Suatu kolektiva sosial merupakan "reality sui generis", artinya kolektiva sosial tersebut telah melahirkan "realitasnya" sendiri yang berbeda dari realitas individu-individu yang menjadi bagiannya. Kolektiva sosial merupakan suatu fenomena yang berdiri sendiri, memiliki pola keteraturannya sendiri yang berbeda dari fenomena individual. Comte menyatakan bahwa sosiologi merupakan studi tentang statika sosial dan dinamika sosial, yang di dalamnya membahas struktur masyarakat. Premis tentang masyarakat sebagai organisme hidup diringkas oleh Spencer sebagai berikut (Margaret, 2004):

Pertama, masyarakat maupun organisme hidup sama-sama mengalami pertumbuhan. Kedua, disebabkan oleh pertambahan dalam ukurannya, maka struktur tubuh sosial maupun tubuh organisme hidup itu mengalami pertambahan pula; di mana semakin besar suatu struktur sosial maka, semakin banyak pula bagian-bagiannya, seperti halnya dengan sistem biologis yang menjadi semakin kompleks sementara ia tumbuh menjadi semakin besar. Ketiga, setiap bagian yang tumbuh dalam tubuh organisme biologis maupun organisme sosial memiliki fungsi dan tujuan tertentu. Keempat, baik dalam sistem organisme maupun sistem sosial, perubahan pada suatu bagian akan mengakibatkan perubahan pada suatu bagian lainnya dan pada akhirnya di dalam sistem keseluruhan. Hal ini berarti bahwa, masyarakat senantiasa tumbuh, berkembang, dinamis, dan kompleks dalam pergerakannya yang orientatif. Meskipun pada tiap bagian yang menjadi unsur-unsur masyarakat tersebut memiliki muatan yang beragam dengan tujuan dan fungsi tertentu, sehingga apabila terjadi perubahan pada suatu bagian akan mengakibatkan perubahan pada bagian yang lain, sampai pada akhirnya dalam sistem keseluruhan di semua tingkat kompleksitas internalnya. Pada tingkat makro, dapat dimungkinkan terjadi perubahan ekonomi, politik, dan kultur. Sementara pada tingkat mezo terjadi perubahan kelompok, komunitas, dan organisasi. Sedangkan pada tingkat mikro terjadi perubahan interaksi dan perilaku individual.

Masyarakat bukanlah sebuah kesatuan fisik, namun merupakan seperangkat proses yang saling terkait bertingkat ganda. Seperti dinyatakan Edward Shils bahwa masyarakat adalah fenomena antar-waktu. Masyarakat terjelma bukan karena keberadaannya di satu saat dalam perjalanan waktu. Masyarakat senantiasa eksis di setiap waktu. Ia ada setiap saat dari masa lalu ke masa mendatang. Eksistensinya justru melalui fase antara apa yang telah terjadi dan apa yang akan terjadi. Dengan begitu, dalam masyarakat terkandung pengaruh, bekas, dan jiplakan masa lalu, serta bibit dan potensi untuk masa depan. Sifat berprosesnya masyarakat secara tersirat bahwa fase sebelumnya berhubungan sebab-akibat dengan fase kini, dan fase kini merupakan persyaratan sebab-akibat yang menentukan fase berikutnya (Piotr, 2007).

Dalam mencapai sebuah keteraturan dalam masyarakat lahirlah sebuah teori struktural konsensus. Teori struktural konsensus merupakan salah satu modus sosiologi untuk menjelaskan keteraturan dan memprediksi kehidupan sosial manusia. Apa yang terjadi pada masyarakat terdahulu dan yang membedakan masyarakat satu dengan masyarakat lainnya, atau manusia dalam masyarakat yang berpikir dan berperilaku berbeda dengan yang lainnya, itu disebabkan karena aturan-aturan yang berlainan mengenai bagaimana harus berpikir atau berperilaku. Jadi, para sosiolog yang menganut teori konsensus menggunakan istilah kebudayaan untuk menjelaskan aturan-aturan yang berlaku dalam sebuah masyarakat. Teori ini sejalan dengan pandangan di atas pada basis teoritis yang sifatnya aksiomatis. Agar semua dapat berjalan dengan baik, maka pada setiap lapisan masyarakat diperlukan suatu mekanisme pengendalian sosial. Mekanisme pengendalian sosial merupakan segala proses yang direncanakan maupun tidak direncanakan untuk mendidik, mengajak, atau bahkan memaksa para warga masyarakat untuk menyesuaikan diri dengan kaidahkaidah dan nilai-nilai kehidupan masyarakat yang bersangkutan.

Dalam bidang transportasi, salah satu sarana yang merupakan bentuk pengendalian sosial yang efektif bagi masyarakat ialah peraturan lalu lintas di mana ketentuan mendasar mengenai masyarakat transportasi diatur dalam Undang-Undang No. 22 Tahun 2009. Ketentuan perundang-undangan tersebut termaktub masyarakat pengguna jalan (Pasal 1 Ayat 27) yang menjadi sub bagian sistem masyarakat transportasi secara keseluruhan. Interaksi antara faktor manusia, jalan, dan lingkungan sangat bergantung dari perilaku manusia sebagai pengguna jalan serta menjadi hal yang paling dominan terhadap keamanan, ketertiban, dan kelancaran lalu lintas (Direktorat Hukum Kementerian Luar Negeri RI, 2020). Masyarakat pengguna jalan adalah sebuah kolektiva sosial di mana seluruh individu yang terdapat di dalam kolektiva sosial tersebut menggunakan jalan untuk berlalu lintas. Adanya sarana dan prasarana jalan telah memberikan pola keteraturannya sendiri bagi setiap orang yang menggunakannya agar dapat berlalu lintas dengan tertib dan lancar. 
Undang-Undang Republik Indonesia Nomor 22 Tahun 2009 tentang lalu lintas dan angkutan jalan, mengenai pengguna jalan pada BAB I pasal 1 ayat 27, pengguna jalan adalah orang yang menggunakan jalan untuk berlalu lintas. Berdasarkan definisi di atas, dapat disimpulkan bahwa persepsi masyarakat pengguna jalan adalah tanggapan (penerimaan) atau rangsangan (stimulus) seseorang dari mengetahui beberapa hal melalui panca inderanya yang menggunakan jalan untuk berlalu lintas. Berikut ini merupakan persepsi yang ada pada masyarakat.

\section{Persepsi Keamanan}

Faktor keamanan dalam bisnis transportasi sangatlah besar perannya. Konsumen sangat berharap keamanan mereka terjamin selama menggunakan jasa transportasi. Adapun keamanan yang diutamakan oleh penumpang adalah keamanan dari tindak kejahatan dan keamanan dari kecelakaan. Kedua kelompok keamanan tersebut dapat mulai dari kecakapan, tindakan, niat dari awak, fasilitas, sarana dan prasarana yang digunakan (Joewono \& Kubota, 2006). Asuransi kejiwaan yang diberikan kepada transportasi online, pengemudi, dan penumpang menjadikan transportasi online yang memiliki tanggung jawab penuh terhadap keselamatan pengemudi maupun penumpang yang menggunakan pelayanan transportasi online (Agustin \& Khuzaini, 2017)

\section{Persepsi Waktu dan Biaya}

Persepsi waktu adalah menyediakan layanan transportasi yang dapat mengantarkan penumpang dengan cepat tanpa harus terkena macet saat di jalan yaitu dengan menggukan jasa go-ride (Manueke, Tampi, \& Londa, 2018). Persepsi biaya adalah tarif yang diberikan untuk transportasi juga dapat dijangkau oleh seluruh lapisan masyarakat, baik itu untuk perjalanan dekat maupun untuk perjalanan jauh. Di sisi lain, tarif yang ditawarkan juga sudah disepakati di awal pemesanan membuat pengguna jasa tidak khawatir mengenai tarif (Manueke, Tampi, \& Londa, 2018).

\section{Persepsi Kemudahan Layanan}

Kemudahan akses mempunyai dampak yang cukup besar bagi konsumen. Berkaitan dengan jasa transportasi, kemudahan yang diperoleh oleh konsumen dalam mendapatkan jasa transportasi, fasilitas, sarana, dan prasarana yang memperlancar akses dalam mendapatkan layanan jasa transportasi (Rosa \& Widad, 2017). Pengguna jasa go-jek mengaku dimudahkan dengan layanan jemput di sebagian besar lokasi. Mereka tidak perlu merasa kesulitan mencari pangkalan ojek maupun angkutan, selain itu memudahkan masyarakat dalam hal pemesanan dan pengantaran makanan, cukup memesan layanan melalui layar smartphone (Manueke, Tampi, \& Londa, 2018).

\section{Persepsi Kemacetan Berkaitan dengan Fasilitas Transportasi Online}

Kemacetan yang terjadi di Jakarta karena adanya penumpukan kendaraan pribadi roda dua maupun roda empat pada mayoritas ruas jalan di Jakarta. Penyebab kemacetan tersebut tidak sepenuhnya adalah kendaraan pribadi. Transportasi yang mungkin bisa diterapkan di Jakarta menurut asumsi masyarakat adalah: monorail, busway, trem, MRT, dan LRT. Pada kenyataannya, warga kota Jakarta mayoritas lebih menginginkan monorail dengan dibuktikan dari 50 orang responden, 48\% diantaranya memilih monorail sebagai sarana transportasi umum modern yag harus dibangun di Jakarta. Busway menempati posisi kedua dengan perolehan minat 38\% dan trem 14\%. Ffek yang mungkin terjadi setelah direalisasikannya sarana transportasi umum modern monorail diperkirakan akan menurunkan jumlah kendaraan pribadi dan membantu mengurangi angka kemacetan di Jakarta (Haryono, Darunanto, \& Wahyuni, 2018).

\section{METODE PENELITIAN}

Penelitian ini menggunakan metode analisis deskriptif yang artinya mendeskripsikan atau memberi gambaran terhadap data yang telah diolah dari hasil penelitian mengenai persepsi masyarakat pengguna jalan terhadap perilaku ojek online pada sudut pandang kemacetan. Data penelitian ini menggunakan data primer. Populasi dalam penelitian ini adalah seluruh masyarakat pengguna jalan yang ada di wilayah Jakarta, Bogor, Depok, Tangerang, dan Bekasi. Teknik pemilihan sampel penelitian menggunakan probability sampling dengan metode insidental sampling yaitu pemilihan responden yang mudah ditemui di lokasi penelitian. Adapun kriteria dalam pemilihan sampel sebagai berikut : masyarakat pengguna jalan yang mengetahui 
tentang transportasi online dan masyarakat pengguna jalan yang memanfaatkan fasilitas transportasi online.

Responden diminta untuk menjawab kuesioner terkait dengan persepsi mereka terhadap ojek online yang terdiri dari persepsi waktu, biaya, kemudahan, keamanan, kemacetan, dan kebutuhan shalter bagi ojek online. Kuesioner terbagi dua bagian, bagian pertama berisi tentang demografi responden dan bagian kedua berisi tentang persepsi masyarakat dengan menggunakan skala likert 6 poin dari skala sangat tidak setuju (skala 1) sampai skala sangat setuju sekali (skala 6). Metode yang digunakan dalam penelitian ini bersifat deskriptif kuantitatif yaitu mengolah hasil koesioner pengguna ojek online. Hasil kuesioner tersebut dilakukan analisis untuk diambil kesimpulan. Adapun analisis yang dilakukan adalah statistik desktiptif, uji validitas dan reliabiltas dan menilai frekuensi jawaban responden untuk diambil kesimpulan.

\section{HASIL DAN PEMBAHASAN}

Mayoritas responden yang mengisi kuesioner merupakan pengguna jasa yang telah disediakan oleh ojek online dengan berbagai produk layanan. Total kuesioner yang dikumpulkan sebanyak 361 kuesioner, namun terdapat responden yang menjawab tidak pernah menggunakan jasa ojek online sebanyak 15 responden atau sebesar 4\% sehingga total kuesioner yang digunakan untuk penelitian ini sebanyak 346 kuesioner atau sebesar $96 \%$.

Tabel 1

Karakteristik Responden Penelitian

\begin{tabular}{|c|c|c|c|c|}
\hline No & Karakteristik & Kriteria & Jumlah & Persentase \\
\hline \multirow{6}{*}{1} & \multirow{6}{*}{ Domisili } & Jakarta & 70 & $20 \%$ \\
\hline & & Bogor & 68 & $20 \%$ \\
\hline & & Depok & 62 & $18 \%$ \\
\hline & & Tangerang & 82 & $24 \%$ \\
\hline & & Bekasi & 64 & $18 \%$ \\
\hline & & Total & 346 & $100 \%$ \\
\hline \multirow{3}{*}{2} & \multirow{3}{*}{ Jenis Kelamin } & Wanita & 237 & $68 \%$ \\
\hline & & Pria & 109 & $32 \%$ \\
\hline & & Total & 346 & $100 \%$ \\
\hline \multirow{9}{*}{3} & \multirow{9}{*}{ Usia } & $<20$ tahun & 4 & $1 \%$ \\
\hline & & $21-25$ tahun & 130 & $38 \%$ \\
\hline & & $26-30$ tahun & 112 & $32 \%$ \\
\hline & & $31-35$ tahun & 55 & $16 \%$ \\
\hline & & $36-40$ tahun & 31 & $9 \%$ \\
\hline & & $41-45$ tahun & 7 & $2 \%$ \\
\hline & & $46-50$ tahun & 4 & $1 \%$ \\
\hline & & $>50$ tahun & 3 & $1 \%$ \\
\hline & & Total & 346 & $100 \%$ \\
\hline \multirow{9}{*}{4} & \multirow{9}{*}{ Pekerjaan } & Dosen & 4 & $1 \%$ \\
\hline & & Guru & 4 & $1 \%$ \\
\hline & & Ibu rumah tangga & 10 & $3 \%$ \\
\hline & & Mahasiswa & 187 & $54 \%$ \\
\hline & & Pegawai negeri & 4 & $1 \%$ \\
\hline & & Pegawai swasta & 131 & $38 \%$ \\
\hline & & Pelajar & 4 & $1 \%$ \\
\hline & & Lainnya & 2 & $1 \%$ \\
\hline & & Total & 346 & $100 \%$ \\
\hline \multirow{6}{*}{5} & \multirow{6}{*}{$\begin{array}{c}\text { Lama Menggunakan Jasa } \\
\text { Ojek Online } \\
\text { (dalam tahun) }\end{array}$} & $<1$ tahun & 66 & $19 \%$ \\
\hline & & $1-2$ tahun & 86 & $25 \%$ \\
\hline & & $2-3$ tahun & 92 & $27 \%$ \\
\hline & & $3-4$ tahun & 67 & $19 \%$ \\
\hline & & $>4$ tahun & 35 & $10 \%$ \\
\hline & & $\begin{array}{c}\text { Total } \\
\end{array}$ & 346 & $100 \%$ \\
\hline
\end{tabular}




\begin{tabular}{|c|c|c|c|c|}
\hline No & Karakteristik & Kriteria & Jumlah & Persentase \\
\hline \multirow{6}{*}{6} & \multirow{6}{*}{$\begin{array}{c}\text { Banyaknya Menggunakan } \\
\text { Jasa Ojek Online } \\
\text { (dalam seminggu) }\end{array}$} & 1 kali seminggu & 160 & $46 \%$ \\
\hline & & 2 - 3 kali seminggu & 97 & $28 \%$ \\
\hline & & 4 - 5 kali seminggu & 49 & $14 \%$ \\
\hline & & $6-7$ kali seminggu & 11 & $3 \%$ \\
\hline & & $>7$ kali seminggu & 29 & $9 \%$ \\
\hline & & Total & 346 & $100 \%$ \\
\hline \multirow{5}{*}{7} & \multirow{5}{*}{$\begin{array}{c}\text { Layanan yang Sering } \\
\text { Digunakan }\end{array}$} & Belanja & 6 & $2 \%$ \\
\hline & & Bepergian & 169 & $49 \%$ \\
\hline & & Pengiriman & 27 & $8 \%$ \\
\hline & & Pesan makanan & 144 & $41 \%$ \\
\hline & & Total & 346 & $100 \%$ \\
\hline
\end{tabular}

Tabel 2

Statistik Deskriptif

\begin{tabular}{lcrrrr}
\hline & N & Minimum & Maximum & Mean & Std. Deviation \\
\hline Persepsi Keamanan & 346 & 20 & 42 & 31,52 & 5,452 \\
Persepsi Waktu & 346 & 14 & 36 & 24,36 & 3,473 \\
Persepsi Biaya & 346 & 4 & 24 & 17,95 & 2,987 \\
Persepsi Kemudahan & 346 & 22 & 42 & 33,01 & 5,071 \\
Persepsi Kemacetan & 346 & 5 & 30 & 17,59 & 4,150 \\
\hline
\end{tabular}

Hasil penelitian ini dapat dijelaskan bahwa keberadaan ojek online memiliki manfaat bagi masyarakat dalam menunjang aktivitas sehari-hari sesuai dengan persepsi masyarakat tentang waktu, biaya, dan kemudahan. Namun, di sisi lain perilaku ojek online dapat menjadi pemicu terjadinya kemacetan di jalan sehingga muncul persepsi keamanan dan kemacetan. Untuk meminimalkan terjadinya kemacetan, dibutuhkan sarana shelter sebagai tempat pick up point dan drop off point pada titik-titik lokasi keramaian seperti universitas, mall, dan stasiun kereta. Tabel berikut adalah penjelasan terkait dengan persepsi masyarakat terhadap ojek online.

Tabel 3

Persepsi Waktu

\begin{tabular}{lccc}
\hline & Freq & Rata-rata Freq & \% \\
\hline Sangat tidak setuju & 19 & 3 & $0,92 \%$ \\
\hline Tidak setuju & 71 & 12 & $3,42 \%$ \\
\hline Kurang setuju & 374 & 62 & $18,02 \%$ \\
\hline Setuju & 1101 & 184 & $53,03 \%$ \\
\hline Sangat setuju & 323 & 54 & $15,56 \%$ \\
\hline Sangat setuju sekali & 188 & 31 & $9,06 \%$ \\
\hline \multicolumn{1}{c}{ Total } & $\mathbf{2 0 7 6}$ & $\mathbf{3 4 6}$ & $\mathbf{1 0 0 \%}$ \\
\hline
\end{tabular}

Sumber : data diolah

Kemacetan merupakan permasalahan utama bagi kota besar seperti Jabodetabek. Beberapa penelitian mengungkapkan bahwa keberadaan transportasi online membantu aktivitas, terutama dalam hal efisiensi waktu. Berdasarkan jawaban responden dalam penelitian ini, persepsi waktu menjadi alasan masyarakat menggunakan layanan transportasi online. Berdasarkan data dari (Inrix.com, 2017) disebutkan bahwa pengendara harus menyiapkan waktu tambahan saat berpergian di Jakarta. Jika lama perjalanan selama satu jam, maka perlu menambah waktu 38 menit di pagi hari dan 51 menit pada sore hari.

Keberadaan ojek online dapat membantu masyarakat dalam memenuhi kebutuhan sehari-hari, diantaranya bepergian, pengiriman, pesan makanan, dan belanja. Ojek online berinisiatif mencari jalan alternatif untuk mempersingkat jarak tempuh. Inisiatif ini dilakukan agar durasi perjalanan dan waktu tempuh dapat lebih efisien dari limit aplikasi terlebih saat terjadi kemacetan di jalan. Ojek online merupakan transportasi berbasis aplikasi online yang dilengkapi dengan Global Positioning System atau yang lebih dikenal GPS untuk memberikan informasi rute terdekat sehingga waktu yang ditempuh lebih efisien. Transportasi umum yang biasa digunakan masyarakat tidak dapat memenuhi seluruh kebutuhan yang lain, maka membuat masyarakat beralih kepada transportasi lain yang lebih mudah dan mempersingkat waktu perjalanan yaitu menggunakan ojek konvensional (Rendy \& Hoetoro, 2018). 
Tabel 4

Persepsi Biaya

\begin{tabular}{lccc}
\hline & Freq & Rata-rata Freq & \% \\
\hline Sangat tidak setuju & 11 & 3 & $0,79 \%$ \\
\hline Tidak setuju & 8 & 2 & $0,58 \%$ \\
\hline Kurang setuju & 97 & 24 & $7,01 \%$ \\
\hline Setuju & 727 & 182 & $52,53 \%$ \\
\hline Sangat setuju & 260 & 65 & $18,79 \%$ \\
\hline Sangat setuju sekali & 281 & 70 & $20,30 \%$ \\
$\quad$ Total & $\mathbf{1 3 8 4}$ & $\mathbf{3 4 6}$ & $\mathbf{1 0 0 \%}$ \\
\hline
\end{tabular}

Sumber : data diolah

Keberadaan ojek online sangat diminati oleh masyarakat, hal ini dikarenakan ojek online memiliki manfaat dalam melayani seluruh aktivitas masyarakat. Biaya yang dikeluarkan oleh pengguna bersifat terjangkau atas jasa yang diterimanya dan telah diketahui saat melakukan pemesanan layanan. Biaya atas layanan ojek online lebih kompetitif dibandingkan dengan transportasi lain yang sejenis, contohnya ojek pangkalan yang kadang kala harga yang ditawarkan tidak relevan dengan layanannya sehingga diperlukan tawar menawar sebelum menggunakan jasanya. Transportasi online menawarkan biaya yang terjangkau, maka tidak mengherankan jika banyak orang yang beralih menggunakan moda transportasi konvensional ke moda transportasi online (Al Mukaromah, Yuliari, \& Ari, 2019).

Tabel 5

Persepsi Kemudahan

\begin{tabular}{lccc}
\hline & Freq & Rata-rata Freq & \% \\
\hline Sangat tidak setuju & 2 & 0 & $0,08 \%$ \\
\hline Tidak setuju & 4 & 1 & $0,17 \%$ \\
\hline Kurang setuju & 56 & 8 & $2,31 \%$ \\
\hline Setuju & 1121 & 160 & $46,28 \%$ \\
\hline Sangat setuju & 673 & 96 & $27,79 \%$ \\
\hline Sangat setuju sekali & 566 & 81 & $23,37 \%$ \\
\hline \multicolumn{1}{c}{ Total } & $\mathbf{2 4 2 2}$ & $\mathbf{3 4 6}$ & $\mathbf{1 0 0 \%}$ \\
\hline
\end{tabular}

Sumber : data diolah

Moda transportasi online selain menawarkan biaya yang terjangkau, juga banyak memberikan kemudahan bagi penggunanya. Kemudahan adalah salah satu alasan yang membuat transportasi online banyak diminati karena penggunaan transportasi berbasis aplikasi online dapat diakses kapanpun dan dimanapun dengan menggunakan smartphone sesuai dengan kebutuhan masyarakat. Hasil penelitian ini membuktikan bahwa kemudahan dalam mengakses transportasi online menjadi kebutuhan akan sarana transportasi yang aman, nyaman, cepat, dan tepat waktu. Responden setuju bahwa transportasi ojek berbasis online memberikan kemudahan kepada mereka dengan penggunaan aplikasi smartphone. Kemajuan teknologi saat ini yang membuat aplikasi transportasi online mudah untuk digunakan dan membantu aktivitas sehari-hari.

Berdasarkan jawaban responden tentang penilaian persepsi kemudahan, penggunaan ojek online dinilai memberikan kemudahan karena layanan ojek online dapat digunakan kapan saja dan di mana saja terutama bagi mahasiswa dan karyawan yang merupakan responden terbanyak dalam penelitian ini. Responden juga menyatakan bahwa transportasi online terutama ojek online memiliki aplikasi yang cara pemesanannya praktis. sehingga memberikan kemudahan dalam mengaksesnya. Hasil penelitian ini membuktikan temuan yang menyatakan bahwa masyarakat saat ini sangat dimudahkan dengan adanya sarana transportasi ojek online terutama untuk pemesanannya, di manapun dan kapan pun secara cepat dan real time, masyarakat mudah melakukan mobilisasi kemana saja dengan memiliki aplikasi yang terhubung dengan teknologi internet ini (Anindhita, Arisanty, \& Rahmawati, 2016). 
Tabel 6

Persepsi Keamanan

\begin{tabular}{lccc}
\hline & Freq & Rata-rata Freq & \% \\
\hline Sangat tidak setuju & 6 & 1 & $0,25 \%$ \\
\hline Tidak setuju & 9 & 1 & $0,37 \%$ \\
\hline Kurang setuju & 241 & 35 & $9,95 \%$ \\
\hline Setuju & 1184 & 169 & $48,89 \%$ \\
\hline Sangat setuju & 470 & 67 & $19,41 \%$ \\
\hline Sangat setuju sekali & 512 & 73 & $21,14 \%$ \\
\hline \multicolumn{1}{c}{ Total } & $\mathbf{2 4 2 2}$ & $\mathbf{3 4 6}$ & $\mathbf{1 0 0 \%}$ \\
\hline
\end{tabular}

Sumber : data diolah

Penilaian responden terhadap persepsi keamanan ojek online dinilai baik. Responden menilai bahwa ojek online sudah cukup memberikan keamanan karena selalu memperhatikan keselamatan para penumpangnya. Dalam hal keselamatan, ojek online sudah dilengkapi sistem keamanan yang terjamin. Lebih lanjut, responden juga menilai bahwa bentuk keamanan yang sudah diterapkan ojek online adalah dengan peralatan dan perlengkapan yang lengkap berupa keseragaman pada pakaian dan helm. Ojek online juga mampu menjawab kekhawatiran masyarakat karena menjunjung tinggi keamanan berkendaraan sesuai dengan moto dari para pemilik ojek online, sehingga menumbuhkan rasa yakin dalam diri masyarakat. Meningkatnya rasa keamanan masyarakat terhadap ojek online juga didukung dengan adanya kelebihan aplikasi data yang dimiliki ojek online untuk dapat mengetahui identitas pengemudi yang berisikan informasi lengkap tentang pengemudi seperti nama, nomor handphone, foto pengendara, dan sebagainya.

Ojek online telah merubah cara pandang masyarakat terhadap tukang ojek yang awalnya dipandang sebelah mata. Perubahan cara pandang tersebut disebabkan karena keberhasilan ojek online meningkatkan citra baik kepada masyarakat terutama terkait dengan keamanan dalam berkendara yang menjadi prioritas (Anindhita, Arisanty, \& Rahmawati, 2016).

Tabel 7

Persepsi Kemacetan

\begin{tabular}{lccc}
\hline & Freq & Rata-rata Freq & \% \\
\hline Sangat tidak setuju & 83 & 17 & $4,80 \%$ \\
\hline Tidak setuju & 181 & 36 & $10,46 \%$ \\
\hline Kurang setuju & 543 & 109 & $31,39 \%$ \\
\hline Setuju & 695 & 139 & $40,17 \%$ \\
\hline Sangat setuju & 137 & 27 & $7,92 \%$ \\
\hline Sangat setuju sekali & 91 & 18 & $5,26 \%$ \\
\hline \multicolumn{1}{c}{ Total } & $\mathbf{1 7 3 0}$ & $\mathbf{3 4 6}$ & $\mathbf{1 0 0 \%}$ \\
\hline
\end{tabular}

Sumber : data diolah

Berdasarkan jawaban responden, menunjukkan bahwa secara tidak langsung ojek online telah menyebabkan kemacetan. Responden menilai masih terdapat perilaku pengemudi ojek online yang berhenti di sembarang tempat untuk mencari penumpang yang secara tidak langsung menjadi pemicu kemacetan dan mengganggu konsentrasi pengguna jalan lainnya. Responden juga menilai terkadang ojek online menggunakan bahu jalan untuk menunggu orderan sehingga meningkatkan kemacetan pada saat jam sibuk.

Jumlah ojek online yang semakin meningkat berdampak pada tingginya tingkat persaingan transportasi ojek online. Meningkatknya jumlah ojek online juga memberikan dampak pada meningkatnya jumlah volume kendaraan yang lalu lalang. Peningkatan kuota ojek online menurut para pemerhati transportasi telah menyumbang kemacetan sehingga diperlukan regulasi yang tepat untuk mengatasi masalah tersebut. Kemacetan lalu lintas yang ditimbulkan angkutan ojek online pada saat mengantar dan menjemput penumpang sudah semakin menimbulkan keresahan pengguna jalan (Fadlilah A., 2019). Untuk itu perlu solusi bagaimana penyediaan area henti ojek online. 
Tabel 8

Kebutuhan Shelter

\begin{tabular}{lcccc}
\hline & & Freq & Rata-rata Freq & \% \\
\hline Ya & 1335 & 267 & $77,17 \%$ \\
\hline Tidak & Total & 395 & 70 & $22,83 \%$ \\
\hline \multicolumn{2}{r}{} & $\mathbf{1 7 3 0}$ & $\mathbf{3 4 6}$ & $\mathbf{1 0 0 \%}$ \\
\hline
\end{tabular}

Sumber : data diolah

Kebutuhan akan shelter dianggap penting oleh masyarakat agar keberadaan ojek online dapat lebih tertib dan tidak menimbulkan kemacetan di jalan raya. Shelter dapat membantu para pengguna ojek online agar dapat dengan mudah menentukan area pick up point untuk penjemputan atau pengantaran penumpang, sehingga ojek online tidak berhenti di sembarang tempat. Responden dalam penelitian ini menilai setuju adanya shelter bagi ojek online agar dapat meminimalkan tingkat kemacetan saat pick up dan drop off penumpang.

\section{PENUTUP}

Hasil penelitian ini menyimpulkan bahwa masyarakat menilai baik atas keberadaan ojek online karena banyak memberikan manfaat bagi masyarakat untuk memfasilitasi kebutuhan sehari-hari. Ojek online dapat memberikan kemudahan dalam bertransportasi dengan aman dan cepat. Ketepatan waktu dan keamanan berkendaraan umum memang faktor utama dalam moda transportasi. Ojek online merupakan transportasi yang dinilai mudah dan cepat dalam hal pemesanan serta tarif relatif murah yang mengakibatkan ojek online menjadi pilihan transportasi yang digemari masyarakat. Selain dampak positif, ojek online memiliki dampak negatif yaitu bertambahnya kemacetan lalu lintas akibat meningkatnya volume kendaraan dan pengunaan bahu jalan saat menunggu orderan. Oleh karena itu, dibutuhkan shelter bagi ojek online agar dapat meminimalkan tingkat kemacetan saat pick up dan drop off penumpang. Saran dalam penelitian ini yaitu perusahaan penyedia jasa angkutan online perlu menyediakan area parkir dan shelter bagi ojek online dengan tujuan mendisiplinkan keberadaan ojek online. Perlu adanya kerjasama antara perusahaan ojek online dengan tempat pengelola mall, stasiun kereta, dan universitas.

\section{DAFTAR PUSTAKA}

Aco, H. (2018, Maret 27). Pengemudi Ojek Online di Jakarta Capai 1 Juta, Tapi Pemerintah Belum Akui Keberadaan Mereka. Retrieved from Tribun Jakarta:

https://www.tribunnews.com/metropolitan/2018/03/27/pengemudi-ojek-online-di-jakarta-capai-1juta-tapi-pemerintah-belum-akui-keberadaan-mereka

Agustin, A., \& Khuzaini. (2017, September). Persepsi Masyarakat Terhadap Penggunaan Transportasi Online (Go-Jek) Di Surabaya. Jurnal Ilmu Dan Riset Manajemen, 6(9), 1-18.

Al Mukaromah, M., Yuliari, K., \& Ari, M. (2019, Desember). Dampak Keberadaan Transportasi On Line Terhadap Kondisi Sosial Ekonomi Transportasi Konvensional di Kota Kediri. JIMEK, 2(2), 168181.

Anindhita, W., Arisanty, M., \& Rahmawati, D. (2016). Analisis Penerapan Teknologi Komunikasi Tepat Guna Pada Bisnis Transportasi Ojek Online (Studi pada Bisnis Gojek dan Grab Bike dalam Penggunaan Teknologi Komunikasi Tepat Guna untuk Mengembangkan Bisnis Transportasi). Prosiding Seminar Nasional INDOCOM (2-3 Mei 2016) (pp. 712-729). Jakarta: Universitas Bakrie.

BPJT. (2018). Badan Pengelola Transportasi Jabodetabek. Retrieved from http://bptj.dephub.go.id/rencanainduk-transportasi-jabodetabek-ritj

Dagun, S. (2006). Busway: Terobosan Penanganan Transportasi. Jakarta: Pustaka Sinar Harapan. 
Direktorat Hukum Kementerian Luar Negeri RI. (2020). Undang-Undang Republik Indonesia Nomor 22 Tahun 2009 Tentang Lalu Lintas dan Angkutan Jalan. Retrieved from PIH Kemlu: https://pih.kemlu.go.id/files/uu_no_22_tahun_2009.pdf

Fadlilah A., S. N. (2019, Desember). Penentuan Area Pick Up Point Ojek Online untuk Mengurangi Kemacetan Lalu Lintas di Sekitar Stasiun Kereta Api Jabodetabek. Jurnal Penelitian Transportasi Darat, 21(2), 145-154.

Haryono, Darunanto, D., \& Wahyuni, R. E. (2018). Persepsi Masyarakat Tentang Kemacetan Lalu Lintas di Jakarta. Jurnal Manajemen Transportasi \& Logistik, 5(3), 277-285.

Joewono, T. B., \& Kubota, H. (2006). Safety and Security in Public Transportation Based on Public Perception in Developing Countries. International Association of Traffic and Safety Sciences., 30(1), 86-100.

Maharani, E. (2018, Agustus 1). Siasat Atasi Kemacetan Karena Ojek Online. Retrieved from Republika: https://www.republika.co.id/berita/kolom/fokus/18/08/01/pco693318-siasat-atasi-kemacetan-karenaojek-online

Manueke, M., Tampi, G. B., \& Londa, V. Y. (2018). Persepsi Masyarakat Tentang Jasa Transportasi Berbasis Aplikasi Online di Kota Manado (Studi Kasus di PT. Go-Jek). Jurnal Administrasi Publik, 4(51).

Margaret, M. (2004). Sosiologi Kontemporer. Jakarta: Raja Grafindo Persada.

Piotr, S. (2007). Sosiologi Perubahan Sosial. Jakarta: Prenada.

Rendy, Y., \& Hoetoro, A. (2018). Analisis Faktor-Faktor Yang Mempengaruhi Permintaan terhadap Ojek Online (Studi Kasus Pada Go-Jek di Kota Malang). Society, 7(1), 1-12.

Rosa, A., \& Widad, A. (2017). Faktor-Faktor yang Membedakan Keputusan Konsumen Menggunakan Jasa Transportasi Dalam Kota (Studi Kasus Angkutan Umum Konvensional dan Berbasis Online). Jurnal Manajemen Dan Bisnis Sriwijaya, 15(3), 164-172.

Sakdiyah. (2019). Hambatan Sosial "Driver" Ojek Online Perempuan (Studi 5 "Driver" Ojek Online Perempuan di Kota Padang). Padang: Universitas Andalas.

Sani, A., Wiliani, N., \& Husain, T. (2019, December). Spreadsheet Usability Testing in Nielsen's Model among Users of ITSMEs to Improve Company Performance. (O. Syniuta, Ed.) European Journal of Scientific Exploration, 2(6), 1-9.

Santoso, S. B., \& Astuti, H. J. (2018). Siklus Hidup Organisasi: Upaya-Upaya Strategis Dalam Menghadapi Gejala Penurunan Organisasi Agar Dapat “Going Concern” Dan Tetap Unggul. EKUITAS (Jurnal Ekonomi dan Keuangan), 9(1), 17-34.

Tamara B., S., \& Sasana, H. (2017). Analisis Dampak Ekonomi dan Sosial Akibat Kemacetan Lalu Lintas di Jalan Raya Bogor-Jakarta. Jurnal Riset Ekonomi Pembangunan (REP), 2(2), 185-196. 